\title{
Managerial networks and strategic flexibility: A QM perspective
}

\author{
Paper published in \\ Industrial Management \& Data Systems
}

Full citation to this publication:

Gutiérrez Gutiérrez, Leopoldo and Fernández Pérez, Virginia (2010): "Managerial networks and strategic flexibility: A QM perspective". Industrial Management \& Data Systems, Vol.110, n.8, pp.1192-1214.

https://doi.org/10.1080/02102412.2010.10779694

Thank you for your interest in this publication. 


\title{
Managerial networks and strategic flexibility: A QM perspective
}

\author{
L.J. Gutierrez-Gutierrez and V. Fernández Pérez \\ Department of Business Administration. \\ Cartuja s/n, 18071. \\ University of Granada. \\ Granada; Spain
}

\begin{abstract}
Purpose - The paper aims to study the effect of external managerial social networks on strategic flexibility for a Quality Management perspective. External social networks can affect strategic flexibility positively. QM also contributes to developing these networks. However, there is currently a wide variety of alternatives for managing quality in organizations, such as ISO Standards or the EFQM model. Thus, different alternatives will influence the external social networks differently in ways that have repercussions for strategic flexibility. Testing these differences is the main purpose of this paper.
\end{abstract}

Design/methodology/approach - 203 valid responses were classified in three groups: NonQM, ISO and TQM firms. Then, a comparative ANOVA analysis was performed to test differences among groups. Finally, different regressions were run to test the effects of external social networks (range, size and strength) on strategic flexibility depending of the observed group.

Findings - Paper results show that depending on QM initiative implemented in the organization, effects of external managerial networks on strategic flexibility vary. Thus, in organizations without QM, the range of external social networks influences strategic flexibility negatively, whereas in organizations with ISO standards, this negative effect 
disappears. In organizations with TQM, we find the positive effect of both size and strength of relations in the networks.

Practical implications - The paper facilitates how to differentiate QM alternatives depending on their observed behaviour.

Originality/value - A new perspective (QM) is observed to test how managerial networks affect strategic flexibility.

Keywords - External managerial social networks, strategic flexibility, Quality Management initiatives

\section{Introduction}

In increasingly unpredictable environments, organizations need the capacity to carry out the strategic changes necessary to find timely solutions to solve the problems they face (Shimizu and Hitt, 2004). Abbott and Banerji (2003) stated that the established paradigm of organizational stability and sustainable competitive advantage has limited applicability and that strategic flexibility solves this problem. Among other positive effects, we find that strategic flexibility ${ }^{1}$ generates better organizational performance (Abbott and Banerji, 2003; Nadkarni and Narayanan, 2007).

As a result of their turbulence, current environments require more information and knowledge. Managers thus play a crucial role (Anderson, 2008), as they make the determining

\footnotetext{
${ }^{1}$ According to Shimizu and Hitt (2004, p.45), "strategic flexibility can be defined as an organization's capability to identify major changes in the external environments (...), to quickly commit resources to new courses of action in response to change, and to recognize and act promptly when it is time to halt or reserve such resources commitments".
} 
strategic decisions for the organization (McDonald and Westphal, 2003; Zaheer and Bell, 2005), using the resources that reach them through their social networks (Geletkanycz and Hambrick, 1997; Ruey-Kei and Jason, 2005). That is, networks provide a link between the environment and the organization and condition the level of adaptation between them. Managers' relations to other people have been widely recognized as a crucial determinant for accessing to information (Anderson, 2008; McDonald, 1992, 1995). Social contacts contribute social capital -benefits resulting from the social structure that organizations can mobilize to facilitate actions (Alder and Kwon, 2002). Despite this evidence, few studies have analyzed the mechanisms by which social networks produce these benefits (Anderson, 2008; Reagans and McEvily, 2003). Most studies assume them causally, as an effect of social structure. Our research test the nexus between the informational benefits of networks and their utility in generating more strategic flexibility and thus, effective utilization of information in the form of organizational response. To explore this relationship in greater depth, we will study how the different dimensions of networks (Collins and Clark, 2003) can have different effects on strategic flexibility, as they contribute resources that are very heterogeneous in quantity and quality. Network dimensions observed include size, range and strength. Network size represents the total group of links that a person has with another ones, total of information channels. Network range represents the diversity of contacts in a social networks, it is, the variety of groups (clients, suppliers, etc.). The strength of the ties ${ }^{2}$ is a multifaceted construct consisting of interaction frequency and the emotional intensity or closeness of a bond (Granovetter, 1973). Therefore, this study proposes first to analyze the relation between external social networks of managers and the organization's strategic flexibility. Findings will contribute to the literature on social networks in organizational behaviour by supporting and

\footnotetext{
${ }^{2}$ In this paper strength of the ties, links or bonds are considered as synonyms.
} 
extending our understanding of the issue of how social network structure is linked the ongoing process of strategic action.

The second task of this paper is to attempt to observe empirically the behaviour of the relationships established between the dimensions of external social networks and strategic flexibility, depending on the QM initiative developed in the organization. The importance of quality management $(\mathrm{QM})$ in current competitive environments has already been shown (Kaynak, 2003; Nair, 2006; Prajogo and Sohal, 2006). In spite of the importance of QM, McAdam et al. (2008) and Mellat-Parast and Digman (2007) argue that there is a need to look at quality management from the strategic view of the firm and we argue the need for the network perspective. There is a serious lack of studies that analyze the relation between QM practices and external social networks. Thus, "there is no evidence on how the principles of quality management can be implemented within a network of firms" (Mellat-Parast and Digman, 2007, p. 804). Mellat-Parast and Digman (2007) propose that organizations should develop a set of practices, in this case QM practices, which are advantageous for networks of firms. A study like that by Flynn and Flynn (2005) finds a positive relation between QM practices and the supply chain. Other studies only propose theoretically the positive effects of QM practices on strategic alliances (Mellat-Parast and Digman, 2007, 2008) or on the supply chain (Lo et al., 2007).

The great evolution that QM has undergone in the last few years has led to the current existence of different options proposed for implementing the practices that this philosophy proposes (García-Bernal et al., 2004; Kumar and Antony, 2008). Familiar examples of these are Quality Control, the American Malcolm Baldrige Model, the European EFQM model, ISO Standards and the most recent Six Sigma methodology. As a result, managers face a wide 
range of possibilities for implementing QM in their organizations (ISO standards, TQM, EFQM model, Malcom Baldrige, etc). In this respect, as a result of the study, we seek to offer firms a criterion of differentiation between three different alternatives (non-QM, ISO Standards and $\mathrm{TQM}^{3}$ ), based on the behaviour of social networks and strategic flexibility. This result will contribute to $\mathrm{QM}$ literature testing the relationship between the implementation of QM initiatives and external social networks effects behaviour.

In summary, the goal of this paper is to study how the dimensions of external social networks (size, range and strength) affect strategic flexibility in the firm and whether there are significant differences in these effects depending on whether the organizations have implemented one QM initiative or another. The paper is structured as follows: after this introduction, we present a literature review that covers the relationship between external social networks and strategic flexibility, and the role of different QM initiatives in the previous relationship. After we review the literature, we describe the methodology and the analysis performed. Subsequently, we discuss the results obtained and present the main conclusions, limitations and recommended directions for future research.

\section{Theoretical background}

\subsection{External social networks as strategic flexibility source}

The importance for firms of adapting to their environments is well-known. One way to achieve a good fit is being strategically flexible (Aaker and Mascarenhas, 1984; Volberda, 1996). Within the organization's dynamic capacities, flexibility has become a capacity crucial to the ability to compete (De Meyer et al., 1989; Koste et al., 2004; Lloréns et al., 2005). Flexibility is the strategic option for situations that the firm cannot anticipate and in which

\footnotetext{
${ }^{3}$ At the present ISO standards are the most extended initiative for QM (Magd and Curry, 2003) and TQM, also constitutes a QM representative initiative as it is associated with other alternatives such us EFQM model (Van Marrewijk et al., 2004), Six Sigma (Green, 2006) or Malcom Baldrige model (Samuelsson and Nilsson, 2000).
} 
there is likely to be a strategic surprise (Volberda, 1998). This paper focuses on strategic flexibility (Volberda, 1996) as a strong indicator of the firm's capacity to adapt (Volberda, 1996) and which has significant repercussions for the firm's performance (Abbott and Banerji, 2003; Nadkarni and Narayanan, 2007).

An organization can create strategic flexibility in many ways, for example, by developing joint systems between organizations and participation in alliances or joint ventures (Butler and Ewald, 2000; Drago, 1997). Managerial social networks are also sources of resources and capacities (Baum et al., 2000; Gulati et al., 2000) that can help the organization to be more flexible. In this article, we focus on the relationship between social networks and strategic flexibility, apart from other ways of flexibility, like operational or structural flexibility (Volberda, 1997, 1998). This is because strategic flexibility is referred to the joined capacities with the organization's goals and with the environmental adaptation to unusual changes (Volberda, 1998). Therefore, strategic flexibility is very sensitive and dependent on information gathering, as social networks.

The role of networks as a path for accessing to information has been shown in prior literature (Anderson, 2008; Cross and Sproull, 2004; Morrison, 2002). Accessing to information through social networks is usually a source of potential opportunities (Alder and Kwon, 2002; Burt, 1992, 2004). Nevertheless, if someone wants to take advantage with these opportunities, it must take into account, among other characteristics, the abilities (Burt et al., 1998) and motivation (Anderson, 2008) that their owners have to use them. Thus, we believe that the effective use of the resources, that networks offer, is more significant for our study because of the essence of society lies in the action processes - not in the structure of relations. No structure of relations is relevant without action (Blumer, 1969). 
In general, the literature supports positive linkages among the access to managers' information and their action repercussions and the corporative outcomes (Dyer and Singh, 1998). Moreover, many authors affirm that social networks increase the ability to respond to unpredictable changes in their competitive environments through the construction of new capabilities (Cross et al., 2001; Lee et al., 2001; Lessard and Zaheer, 1996; Liebeskind et al., 1996) and behavioural flexibility (Zaccaro et al., 1991). The quantity and the quality of obtained information through the networks could be decisive for effective and quick adaptation or for anticipating or changing the environment. Thus, it is logical to propose a nexus of influence among these variables (social networks dimensions and strategic flexibility).

The size and range of the network and the strength of the links are three primary variables of social networks structures (Collins and Clark, 2003; Cross and Cummings, 2004; Gabbay and Leenders, 2001; Reagans and McEvily, 2003). Network size is important because each link that a person has represents an information channel. Network range represents the diversity of contacts in social networks. When a manager tries to access information to become aware of an issue, a greater number and diversity of contacts makes it more likely that someone can provide the information he or she needs. The literature suggests that large and diverse networks generate a greater variety of perspectives and stimulate criticism, given that they have more access to new and diverse information (Burt, 1992). When it takes into account the opinions of different audiences, every people are better prepared to anticipate different contingencies (Burt, 2004; McDonald et al., 2008; Reagans and Zuckerman, 2001). It can favour the emergence, combination or recombination of good and new ideas and actions (Obstfeld, 2005). Large and diverse networks have greater capacity to gather information than 
small ones (Burt, 1982; Granovetter, 1973). In this sense, executives who use more sources of information have greater access to competitive ideas and opportunities and better results (Dussauge et al., 2000; McEvily and Zaheer, 1999; Zaheer and Bell, 2005; Zaheer and Zaheer, 1997). We can thus propose the following hypotheses:

\section{H1: External social networks of managers that have a greater size are related positively to some greater levels of strategic flexibility in organizations. \\ H2: External social networks of managers that have a greater range are related positively to some greater levels of strategic flexibility in organizations.}

Another key concept of networks that affects information flows is the strength of the links. Strong networks facilitate the exchange of detailed information (Krackhardt, 1992; Uzzi, 1996), due to the fact that these networks are characterized by frequent interaction, a common history and mutual trust (Anand and Khanna, 2000; Granovetter, 1982, 2005). This means that they require more maintenance, which implies that the volume of information will be smaller, although higher in quality (Dyer and Nobeoka, 2000). This usually brings better results (Lorenzoni and Lipparini, 1999; Zaheer et al., 1998) and competitive capacities (McEvily and Marcus, 2005).

Given the foregoing, this paper proposes that managerial social networks provide greater levels of access to information and higher-quality information. Thus, it can be related to effective and rapid strategic actions, generating greater organizational strategic flexibility.

This leads us to articulate the following hypothesis: 


\section{H3: External social networks of managers that have a greater strength are related positively to some greater levels of strategic flexibility in organizations.}

Insert Figure I about here

\subsection{Quality Management initiatives and external social networks}

Few studies in the literature analyze the relation between quality management and external social networks. However, we find some studies that observe the effect of quality management practices on particular cases. The contact most analyzed is that of the supply chain. In this case, for example, Flynn and Flynn (2005) find a very strong positive relation between QM and the supply chain. To show this, they observed the positive effect of QM practices on goals for supply chain management (flexibility, delivery or inventory turnover) Likewise, Lin et al. (2005) showed empirically that QM practices affect the relationship with the supply chain positively. In contrast, Mellat-Parast and Digman $(2007,2008)$ focus on the case of strategic alliances. For this situation, they developed a model and a series of propositions that affirm the direct and indirect positive effect of all of QM inherent practices on the performance of strategic alliances. These are two examples of positive relations of quality management practices on external contacts with providers and other firms. However, the same result would occur with other contacts, such as those with customers, competitors or financial institutions. Thus, practices such as orientation to the customer, which constitute one of the principles of quality management (Dean and Bowen, 1994; Prajogo and Sohal, 2003; Sitkin et al., 1994), cultural change (Black and Porter, 1996; Douglas and Judge, 2001) or benchmarking activities (Ahire et al., 1996; Powell, 1995) will collaborate in the development of these networks and specifically for accessing to information. Supplier management, quality data reporting, trust, knowledge sharing or cooperative learning are some examples of 
elements that benefit clearly accessing to information due to the fact that they facilitate and stimulate the relationship between social networks members (Lin et al., 2005; Mellat-Parast and Digman, 2007, 2008).

The positive effect of quality management practices on external social networks seems clear. However, the degree to which these practices develop is not the same in all QM initiatives (Gutiérrez et al., 2010). Currently, for example, the most widely QM initiative used is the implementation of ISO Standards. The literature on QM shows that ISO Standards lead to higher levels of QM practices implementation than basic QM (Gotzamani, 2005; Vouzas and Gotzamani, 2005). But also, these standards represent a significant initial step for manufacturing organizations on the way to TQM, since they involve a lower initial degree of commitment to their principles. Thus, elements such as employee involvement (Casadesús and De Castro, 2005) and employee work attitude (Van der Wiele et al., 2005) have created some controversy. Some studies rank TQM above ISO Standards (Bendell, 2000), although others argue that the new version of ISO Standards has some quite close to TQM (Boulter and Bendell, 2002; Gotzamani, 2005; Vouzas and Gotzamani, 2005).

These differences between ISO Standards and TQM and, obviously, between both and basic Quality Control, lead us to establish that there are different alternatives for QM, whose elements development degrees differ among them. Thus, the development of the QM elements depends on the QM initiative in use (ISO Standards, Quality Control, Malcolm Baldrige, Six Sigma, EFQM, etc.). Elements such us leadership, product/service design, supplier management, process management, etc., as we observed, have a positive effect on external social networks. However, if the elements development degrees differ among QM initiatives, their effects on external social networks probably will be different. This study will 
therefore attempt to observe whether the effects included in Hypotheses 1, 2 and 3, differ depending on whether the organizations observed have implemented one QM initiative or another. We thus propose the fourth hypothesis:

\section{H4: The effect of the dimensions of external social networks of managers (size, range and strength) on organizational strategic flexibility differs between non-QM organizations, organizations with ISO Standards, and TQM organizations.}

\section{Research method}

\subsection{Data sample}

The context chosen to test these hypotheses is the geographical region of Spain. We selected this area to minimize the impact of variables that we cannot control in the empirical research. Literature recommends selecting a sample of firms located in a relatively homogeneous geographical, cultural, legal and political space (Alder, 1983; Hofstede, 1980).

We conducted systematic random sampling of 900 companies from a mailing list Amadeus database and Dun and Bradstreet Spain (Ryu and Eyuboglu, 2007). The search criterion was medium-sized and large manufacturing (387) and services firms (513), as defined by the guidelines of the Fourth European Directive ${ }^{4}$ (2009). Because our research focuses on strategic flexible actions - that is, on decisions that depend on the CEOs of the companieswe chose CEOs as the key informants. The procedure for data collection consisted of sending a letter by mail (754 questionnaires) or email (146 questionnaires), to different Spanish firms’

\footnotetext{
4 "Small" companies are companies which do not exceed the limits of two of the following three criteria (in milions EUR): a) balance sheet total: < 5; b) annual sales: < 7 and c) number of employees: < 50. "Mediumsized" companies are companies which achieve at least two of the following three criteria: a) balance sheet total: 5-27; b) annual sales: 7-40 and c) number of employees: 51-250. "Large" companies are companies which achieve at least two of the following three criteria: a) balance sheet total: $>27$; b) annual sales: $>40$ and c) number of employees: $>250$.
} 
CEOs. The letter explained the reasons for and objectives of the research. Finally, questionnaires answered could be sent back by mail or email.

The questionnaire was developed after an extensive review of the literature related to main constructs observed. Once designed, the questionnaire was pretested by three Spanish managers, which enabled the clarification of possible ambiguities, correction of errors and solution of formatting problems. We received 226 questionnaires, of which 203 were valid. The response rate was $22.6 \%$. The response rate by mail was $20.1 \%-152$ received- and by email $34.9 \%-51$ received-. The response rate by economic sector was $24.3 \%$ manufacturing firms -94 received- and $21.2 \%$ services firms -109 received-.

Of the total of 203 firms, $5.9 \%$ reported annual sales of 7 million euros or less, and $27.6 \%$ of the firms had annual sales between 7 and 40 million of euros. The firms that had annual sales of more than 40 million of euros comprised about $66.5 \%$. As to the number of employees in each of the firms surveyed, $9.8 \%$ of the firms had less than 50 employees, $29.6 \%$ from 51 to 250, and $60.6 \%$ over 250 workers. According to the previous guidelines of the Fourth European Directive (2009), companies were categorized in the group in which achieve at least two of the three criteria of the Directive. The result showed that $43.3 \%$ were medium-sized companies and the $56.7 \%$ were large companies.

Using the same database, we checked for non-response bias. This source also provided the archival data concerning the annual sales incomes and number of employees of the responding firms and a sample of non-responding firms. The difference of means between the responding and non-responding companies concerning these variables were tested using two independent samples t-test. The results demonstrated that all t-statistics were non-significant 
at the level of 0.05 . (The p-values for these comparisons ranged from .25 to .55). Since the questionnaire was answered by a single informant, we also checked for common method bias using Harman's one-factor test. A principal factor analysis of all measurement items yielded 7 factors with eigenvalues larger than one. These factors accounted for $52 \%$ percent of the variance. Since the first factor accounts for $21 \%$ of variance (less than half of the variance explained by the set of factors with eigenvalues greater than one), common method variance is unlikely to be a serious problem in the data (Podsakoff and Organ, 1986).

\subsection{Measurement and tests for reliability and validity (see Appendix A)}

\section{Independent variable: External social networks of managers}

External social networks of managers were measured observing the size, range and strength of the links that they maintain with their contacts (Collins and Clark, 2003) in seven categories: board directors same industry, board directors other industries, suppliers, clients, financial institutions, competitors and other companies' partners. The size of the network refers to the number of the director's contacts that give him/her relevant information (see Appendix A). To measure this rate, we asked directors to identify the number of their relevant contacts for each of the seven external categories (Collins and Clark, 2003; Hansen, 1995), using a Likert-type scale of 7 points where 1 indicates "none", 2 "few (1-3)" and 7 "many (>25)" to respond to the following question: "On average, how many people are important sources of information regarding important business or industry trends and issues?" (Cronbach's Alpha=0.841). The range of the network represented the diversity of the respondent's contacts. Network range observes if managers interact with different contacts (suppliers, customers, etc.) or only with one or two contacts, for example, other managers. Higher contact diversity leads to more complete information, as it comes from different sources. This variable was measured as the number of different categories which the manager has contact with, considering the seven categories observed (Powell and Brantley, 1992; Scott, 1991). Tie strength was 
operationalized as an index measuring frequency of communication or interaction and emotional intensity or closeness of the relationship (Fischer, 1982; Hansen, 1999; Marsden and Campbell, 1984; Reagans and McEvily, 2003). The frequency of the relationship was provided through the responses to the question: "On average, how often do you communicate with each category?" Emotional intensity was measured through the response to the question: “On average, how would you describe your relationship with each category?" For these cases, we provided a 7-point Likert scale to which the CEO's could respond. In the case of frequency, 1 indicated "very often" and 7 "very infrequently." In the second case, 1 indicated "distant or very far" and 7 "very close" (reverse-score). Strength was measured jointly as the average of the standardized values of frequency of the relationship and emotional intensity (Collins and Clark, 2003, Granovetter, 1973) (Cronbach's Alpha=0.71).

\section{Dependent Variable: Organizational strategic Flexibility}

An adaptation of a scale develop by Verdú, Lloréns and García (2004) has been used, which is a synthesis of the contributions of Volberda $(1996,1998)$, since the perspectives of the studies were similar. Our research is based on a large number of firms and performs crosssectional analysis. Finally, managers had to indicate their level of agreement or disagreement with the statements (see Appendix A), using a seven-point Likert-type scale (Cronbach's Alpha $=0.865)$.

To complete validation, all scales were subjected to a confirmatory factor analysis (CFA) using the computer programme LISREL 8.53., to guarantee the scales' convergent and discriminant validity (see Appendix B). According to Hulland (1999), there are three conditions for scale convergent validity. Firstly, factorial loadings must be significant $(t>1.96$; $\mathrm{p}<0.05$ ); secondly, these loads must be over 0.4 ; finally individual reliability must exceed 
$50 \%$. Values obtained in the analysis were higher than the established minimums (Howell, 1987; Hulland, 1999; Szulanski, 1996), so convergent and discriminant validity were guaranteed.

\section{Classification variable: Implementation of quality management initiatives}

To identify the implementation of quality management initiatives, the questionnaire included a list of the different alternatives (non-QM, ISO Standards and TQM). The firms would choose the initiatives that they had underway.

\section{Control variables: Incomes}

Large companies have a greater number of advantages due to their resources (Barney, 1991). Therefore, we include annual sales incomes as control variable. Different income levels affect to the information required from external networks, to carry on flexible behaviours and to QM implementation.

\section{Data analysis}

\subsection{Sample distribution}

We began the investigation by dividing the total sample obtained $(n=203)$ into three groups. For the first group, we selected firms that did not choose any of the quality management initiatives included in the questionnaire. Non-QM firms group was composed of 73 organizations. The second group included organizations that had implemented only the ISO standards. This second group (ISO firms) was formed of 67 organizations. Finally, in the third group we included those firms that had chose the TQM initiative or the EFQM model, having or not the ISO standards implemented. This group (TQM firms) was composed of 63 organizations. Table I includes group distribution, means, standard deviations, medians, maximum and minimum for each observed variable. For all four variables observed, highest 
means values are associated with TQM firms group, followed by Non-QM firms group and finally by ISO-firms group. This aspect will be considered in the discussion section. Distribution of number of employees and annual sales is also included in Table I to complete information about the three groups observed.

Insert Table I about here

\subsection{ANOVA analysis}

Once the sample was distributed into the three groups described, using the statistical program SPSS 15.0, we performed an ANOVA analysis of the means of the three groups relative to all observed variables "size", "range" and "strength" of external social networks and strategic flexibility. This test enabled us to observe if the observed variables generate significant differences among the three groups. Independence and homocedasticity of residuals were confirmed. Since the residuals have a normal distribution, the variables observed, also are normally distributed. The results of the comparisons of means are shown in Table II. All variables, size $(\mathrm{F}=7.822 ; \mathrm{p}=.001)$, strength $(\mathrm{F}=6.793 ; \mathrm{p}=.001)$, range $(\mathrm{F}=6.931 ; \mathrm{p}=.001)$ and strategic flexibility $(\mathrm{F}=15.025 ; \mathrm{p}=.000)$ generates significant differences between groups.

Insert Table II about here

\subsection{Regression analysis}

In order to contrast the hypotheses 1, 2 and 3, we proceed to study the relations of the variables amongst themselves. To achieve this, we perform a regression analysis by steps for each of the groups. Before performing this analysis, we assessed the assumptions of multiple 
regression analysis. Thus, linearity, homoscedasticity, normality and multicollinearity assumptions were observed. Results showed that all these assumptions could be checked.

Table III shows the results of the regression analysis for the independent variables size, strength and range and the dependent variable strategic flexibility, for each of the groups analyzed. Independent variable "Incomes" is used as control variable. There is not any significant difference between groups. Therefore, income level is not determining factor for flexibility level, independently of QM initiative implemented. As we can see, the variable "size of network" was included as a significant variable in the three regressions $(\mathrm{t}=6.801$, $\mathrm{p}=.000 ; \mathrm{t}=3.218, \mathrm{p}=.002 ; \mathrm{t}=3.576, \mathrm{p}=.001$, to non-QM group, ISO group and TQM group respectively). Thus, Hypothesis 1 for size founds strong support. However, there are differences in the other variables. Thus, in addition to size, for Non-QM group, the range exercises a negative and significant influence on strategic flexibility $(\mathrm{t}=-2.882, \mathrm{p}=.005)$. If we study ISO group and TQM group, this significant influence does not occur. Hypothesis 2 for range is supported for only non-QM firms. Finally, TQM group adds a positive and significant effect of strength on strategic flexibility $(\mathrm{t}=2.566, \mathrm{p}=.013)$. Hypothesis 3 for strength is supported for only TQM group. We find that external social networks influence organizational strategic flexibility positively through their dimensions, except in the first case, where the range has a negative influence. . On the other hand, there are differences in the effects of the variables "size", "strength" and "range" on strategic flexibility, depending on the quality initiative implemented in the organization. Based on this result, we can support Hypothesis 4. Figure II represents graphically all the significant effects contrasted in the relationships between variables, according to groups observed.

Insert Table III about here Insert Figure II about here 


\section{Discussion}

In turbulent environments like the present one, strategic flexibility helps organizations to confront their changes in an opportune and efficient way and facilitates the organization's adaptation or transformation if necessary (Nadkarni and Narayanan, 2007; Shimizu and Hitt, 2004). External managerial social networks can aid, since they contribute, as has been demonstrated in this research, to the generation of such flexibility. This shows the value of focusing on the composition, development and evolution of the organization's managerial social networks (Hallikas et al., 2008), since the extent of their effects can condition key capabilities for the organization (Campbell-Kelly et al., 2008) and influence their competitiveness $(\mathrm{Wu}, 2006)$. Interrelations with other social agents enable them to acquire a joint vision of their multiple demands and points of view (De Clercq and Dimov, 2008), and they are ensured excellent opportunities to take advantage of experience, knowledge or simply information from these agents that can be useful to them (Dyer and Nobeoka, 2000, Acquaah, 2007). Besides, our results lead to important managerial implications, affecting their strategic decisions and, consequently, organizational performance. These conclusions suggest that specific network-building practices may be an effective means for firms to purposefully manipulate the networks of their top managers.

\section{External social networks of managers and organizational strategic flexibility}

Increased instability in most industries means that contacts (the information and knowledge or references that they transmit to us) can form the basis of a competitive advantage (Gulati et al., 2000; Moran, 2005). This fact is demonstrated in our empirical study, since we see that 
network size has a positive, direct and significant effect on strategic flexibility in all groups. Strength of the networks in TQM firms also has this positive effect. This information tells us that the proper combination of all of the dimensions can optimize the results (Gilsing and Duysters, 2008), as they contribute different but interesting benefits. In general, our information reinforces the importance of contacts, which can come to be crucial strategic assets, even in prosperous or stable situations (Kang, 2008). It is worth mentioning the case of organizations that have no initiative for quality management, which show a negative and significant relation between range and strategic flexibility. We will discuss this problem later.

External social networks of managers, organizational strategic flexibility and $Q M$ initiatives

In comparing the three groups created (ANOVA analysis), we first find that the level of strategic flexibility developed is different in each case. If we compare the group of non-QM and ISO firms (4.21 and 4.12, respectively), strategic flexibility is quite similar between both groups. In the case of the group of TQM firms, we see that strategic flexibility is developed to a much greater extent (5.01), than in the other two cases. According to the theoretical reasoning followed, it seems logical that a lower degree of development of the QM elements leads to a lower degree of development of strategic flexibility, as occurs in the group of nonQM firms. However, such results would be surprising in the case of ISO-firms. If we begin with the TQM-firms, Rajagopal et al. (1995) shows TQM to be a method that improves organizational efficacy and flexibility. Continuous improvement and orientation to the customer make organizations more sensitive to changes in the environment (Hackman and Wageman, 1995), enabling them to adjust better to the demands of the environment (Youssef et al., 1996; Zairi, 2002), thus making them more flexible (Gómez-Gras and Verdú, 2005; Lloréns et al., 2004). Empirically, the positive relation between TQM and flexibility has been 
demonstrated (Gómez-Gras and Verdú, 2005; Lin and Chang, 2006; Lloréns et al., 2004; Merino-Díaz, 2003). However, some time ago, Manz and Stewart (1997) present the possibility associated with a case of quality management. The standardization and conformity proposed by QM (not TQM) can make the firm static. One example of this situation could be ISO Standards. Lundmark and Westelius (2006) analyzed Swedish SMEs that had been certified with both the 1994 and then the 2000 ISO Standards. The greatest problem that they encountered was the excessive bureaucracy associated with the norm, which according to managers can lead to reduced flexibility. Our results point to this line of investigation. It is important, therefore, to differentiate explicitly between ISO Standards and TQM, as there are significant differences like those we have just observed. Therefore, as this is not the first research showing that ISO standards lead to a lower level of flexibility than other initiatives, such as TQM, managers should considered this fact when they evaluate different alternatives to implement $\mathrm{QM}$ in their organizations. Completing this information for managers, significant differences observed between three groups, shows that TQM firms, also are those with highest level of external network dimensions. ANOVA analysis showed significant differences between the three groups in all variables observed for external network (size, strength and range). Differences are more significant comparing TQM-firms group with NonQM group and ISO-firms group, as happened with strategic flexibility. TQM organizations seem to be more involved for QM, with higher levels of QM structural elements (Gutiérrez et al, 2010), and as a result, aspects such us external networks or strategic flexibility improve. All these differences lead to important managerial implications. As we have observed, at the present, managers face a wide range of possibilities for implementing QM in their organizations (TQM, ISO standards, Six Sigma, etc). Our conclusions may help them with this kind of decision, as the fact that TQM firms develop to a greater extent strategic 
flexibility and external networks dimensions, is an important aspect that should be consider when TQM alternative and ISO standards alternative are compared.

In relation to the effects of the dimensions on flexibility, the dimension of size affects strategic flexibility positively in the three groups observed. As we established, a greater number of contacts generates a higher number of points of view, which contributes to knowing more ideas and creating new ones (Burt, 1992; Obstfeld, 2005).

Strength has a strong positive effect on strategic flexibility in TQM firms. These organizations are characterized by developing QM practices to a greater extent than those belonging to the other two groups. The literature has indicated the positive effect of QM on networks, through practices such as trust, leadership, process management, learning, etc. (Flynn and Flynn, 2005; Lin et al., 2005; Mellat-Parast and Digman, 2007, 2008). Strength is developed significantly to a greater extent in TQM firms than in ISO firms or non-QM firms (see Table 1), constituting an example of QM's contribution to external networks. For example, we have mentioned the importance of trust, a key element in TQM in forging strong relations (Larson, 1992; Dyer and Nobeoka, 2000; Lorenzoni and Lipparini, 1999; Zaheer et al., 1998). On the other hand, strong networks require detailed information exchange (Krackhardt, 1992; Uzzi, 1996) characterized by frequent interaction (Granovetter, 1982). This study has shown that TQM firms generate greater strength in external social networks through their structural practices, including supply management, cooperation, benchmarking, knowledge sharing or learning, develop stronger external social networks, which contribute significantly to organizational strategic flexibility. 
Finally, it is important to pause over the negative effect detected in the case of the dimension "range" for non-QM firms. This result implies that, as the different categories of agents with which we associate increase, strategic flexibility decreases. Prior studies have analyzed the range within specific categories, such as managers (Geletkanycz and Hambrick, 1997; McDonald et al., 2008), customers (Park and Lou, 2001), providers (Peng and Lou, 2000) and competitors (Von Hippel, 1988). Among these, diversity is usually positive, as it helps to propose innovative strategies or ideas that differ from the ideas already in use (McDonald and Westphal, 2003; Reagans and McEvily, 2003). However, when one takes into account many different categories of agents at one time, dispersion can be counterproductive. A greater range implies a greater number, complexity and even juxtaposition of ideas and information received. This can lead to immobility or delayed reactions (Simon, 1959; Szulanski, 1996). Although variety increases the range of the organization's potential behaviours, it can also create confusion and generate costs (Borgatti and Cross, 2003). Thus, this result can be due to the high number of categories of different agents that were used. However, in observing the range in the other two groups, we confirm that-in spite of the fact that it is lower for the group of ISO-firms and higher for the group of TQM-firms - its influence is not significantly negative for any of the cases. What we can observe is that the value of the $R^{2}$ shows a decrease in the importance of the effect of the dimensions of external social networks on strategic flexibility when we move from non-QM firms to ISO-firms or TQM-firms. This result shows that the effect of external social networks on strategic flexibility has much more weight in the non-QM firms. An explanation for this could be that as Shimizu and Hitt (2004) showed there are a series of factors that exercise a very important influence on strategic flexibility, such as strategic leadership, creating dynamic mechanisms to gain new ideas, stimulating decision-making processes, measuring and monitoring decision outcomes, learning, etc. These factors are clearly associated with QM and correspond more closely to the 
ISO-firms and TQM-firms than to the non-QM firms. This justifies the loss of importance of external social networks vis à vis the other aspects. Future lines of research could focus on this problem.

\section{Limitations and further research}

Among the limitations of our study, we must include the fact that QM alternative implementation is observed using a single item, instead of a compound construct. The sample of firms is not distributed uniformity according to the number of employees and annual sales incomes. Together with the cross-sectional character of the research, this factor somewhat limits generalization from these results. Thus, longitudinal research that analyses a greater number of cases and that observes effects on different kinds of organizations could enrich the literature on the external social networks and quality management initiatives.

Further, one could analyze internal managerial social networks, as well as those established between workers themselves, to determine their effects on the generation of different dynamic capabilities. We intuit that these are a significant direct and moderating variable, as they would influence the levels of capturing, creating and transforming resources. On the other hand, one could study the influence of the social networks on the different kinds of flexibility (strategic, structural and operative). This would deepen our understanding of the influences of managerial networks on strategic and structural levels, as well as the effects of the networks with workers and the influence of networks between workers on levels of operational flexibility. Finally, establishing direct multiple comparisons between these (ISO and TQM) and other QM initiatives (EFQM model, Quality Control, Lean Manufacturing) could bring deeper understanding of their functioning, helping managers differentiate between them. 


\section{Conclusion}

This paper has attempted to observe the effect of external social networks on organizational strategic flexibility. It also includes the factor of quality management and how this effect can be influenced by the kind of quality management initiative that organizations are implementing. The results obtained indicate the existence of a positive global effect of external social networks on strategic flexibility, mainly through their dimension of size. Thus, larger external social networks contribute positively to strategic flexibility.

The study also provides evidence that external networks serve as important informational resources for firms. From a practical standpoint, it appears that firms may be able to purposefully develop and manage the networks of their top managers. However, since different network characteristics affect firm performance differently, companies should be careful to create the network characteristics that are most likely to affect performance in their particular environmental context.

On the other hand, if we divide the sample into non-QM firms, ISO-firms and TQM-firms, we can draw two important conclusions. First, TQM-firms develop all of the dimensions of external social networks and strategic flexibility to a greater extent. This does not occur for non-QM and ISO-firms. We can explain this result through the risk of excessive bureaucracy associated with ISO Standards. Second, we see that the importance of the influence of the dimensions of external social networks on strategic flexibility decreases significantly when we move from non-QM firms to ISO-firms and TQM-firms, with other factors inherent in them, such as strategic leadership, learning or stimulating decision-making processes, possibly achieving more relevance. 


\section{References}

Aaker, D.A. and Mascarenhas, B. (1984), "The need for strategic flexibility", Journal of Business Strategy, Vol. 5, pp. 74-82.

Abbott, A. and Banerji, K. (2003), "Strategic flexibility and firm performance: the case of US based transnational corporations", Global Journal of Flexible Systems Management, Vol.4, No. 1-2, pp. 1-9.

Acquaah, M. (2007), "Managerial social capital, strategic orientation, and organizational performance in an emerging economy", Strategic Management Journal, Vol. 28, pp. 12351255.

Ahire, S.L., Golhar, D.Y. and Waller, M.A. (1996), "Development and Validation of TQM Implementation Constructs”, Decision Sciences, Vol. 27, No. 1, pp. 23-56.

Alder, N.J. (1983), “A typology of management studies involving culture”, Journal of International Business Studies, Vol. 14, No. 2, pp. 29-47.

Alder, P. and Kwon, S. (2002), "Social capital: prospects for a new concept", Academy of Management Review, Vol. 27, pp. 17-40.

Anand, B.N. and Khanna, T. (2000), "Do firms learn to create value? The case of alliances", Strategic Management Journal, Vol. 21, pp. 295-315.

Anderson, M.H. (2008), "Social networks and the cognitive motivation to realize network opportunities: a study of manager' information gathering behaviours", Journal of Organization Behavior, Vol. 29, pp. 51-78.

Barney, J.B. (1991), "Firm resources and sustained competitive advantage", Journal of Management, Vol. 17, pp. 99-120.

Baum, J.A.C., Calbrese, T. and Silverman, B.S. (2000), "Don't go it alone: alliance network composition and start-ups' performance in Canadian biotechnology", Strategic Management Journal, Vol. 21, pp. 267-294.

Bendell, D. (2000), "The implications of the changes to ISO 9000 for organisational excellence", Measuring Business Excellence, Vol. 4, No. 3, pp. 11-14.

Black, S. and Porter, L. (1996), "Identification of the critical factors of TQM", Decision Sciences, Vol. 27, No. 1, pp. 1-21.

Blumer, H. (1969), Simbolic interactionism. Berkeley, CA. University of California Press.

Borgatti, S.P. and Cross, R. (2003), “A relational view of information seeking and learning in social networks", Management Science, Vol. 49, No. 4, pp. 432. 
Boulter, L. and Bendell, T. (2002), "How can ISO 9000.2000 help companies achieve excellence?", Measuring Business Excellence, Vol. 6, No. 2, pp. 37-41.

Burt, R.S. (1982), Toward a structural theory of action. New York: Academic Press.

Burt, R.S. (1992), Structural holes; the social structure of competition. Cambridge, MA. Harvard University Press.

Burt, R.S. (2004), "Structural holes and good ideas", American Journal of Sociology, Vol. 110, pp. 349-455.

Burt, R.S., Jannotta, J.E. and Mahoney, J.T. (1998), "Personality correlates of structural holes", Social networks, Vol. 20, pp. 63-87.

Butler, T.W. and Ewald, J. (2000), "The fundamentals of flexibility", Research and perspectives on healthcare, Vol. 78, No. 3, pp. 11-18.

Campbell-Kelly, M., Garcia-Swartz, D.D. and Layne-Farrar, A.L. (2008), "The evolution of network industries. Lessons from the conquest of the online frontier, 1979-95", Industry and Innovation, Vol. 15, No. 4, pp. 435.

Casadesús, M. and De Castro, R. (2005), "How improving quality improves supply chain management. empirical study", TQM Magazine, Vol. 17, No. 4, pp. 345-357.

Collins, C.J. and Clark, K.D. (2003), "Strategic human resource practices, top management team social networks, and firm performance. The role of human resource practices in creating organizational competitive advantage", Academy of Management Journal, Vol. 46, No. 6, pp. 740-751.

Cross, R. and Cummings, J.N. (2004), “Tie and networks correlates of individual performance in knowledge intensive work", Academy Management of Journal, Vol. 47, No. 6, pp. 928.

Cross, R. and Sproull, L. (2004), "More than an answer: information relationships for actionable knowledge”, Organization Science, Vol. 15, No. 4, pp. 446-463.

Cross, R., Parler, A., Prusak, L. and Borgatti, S.P. (2001), "Knowing what we know: supporting knowledge creation and sharing in social networks", Organizational Dynamic, Vol. 30, pp. 100-120.

De Clercq, D. and Dimov, D. (2008), “Internal Knowledge Development and External Knowledge Access in Venture Capital Investment Performance", Journal of Management Studies, Vol. 45, No. 3, pp. $585-612$.

De Meyer, A., Nakane, J., Miller, J.G. and Ferdows, K. (1989), "Flexibility: The Next Competitive Battle-The Manufacturing Futures Survey", Strategic Management Journal, Vol. 10, pp. 135-144. 
Dean, J.W. Jr. and Bowen, D.E. (1994), “Management Theory and Total Quality. Improving research and practice through theory development", Academy of Management Review, Vol. 19, No. 3, pp. 392-418.

Douglas, T.J. and Judge, W.Q. Jr. (2001), “Total Quality Management Implementation and Competitive Advantage. The role of structural control and exploration", Academy of Management Journal, Vol. 44, No. 1, pp. 158-169.

Drago, W.A. (1997), "When strategic alliances make sense”, Industrial Management and Data Systems, Vol. 97, No. 2, pp. 53.

Dussauge, P., Garrette, B. and Mitchell, W. (2000), "Learning from competing partnert. Outcomes and durations of scale and link alliances in Europe, North America, Asia”, Strategic Management Journal, Vol. 21, No. 2, pp. 99.

Dyer, J.H. and Nobeoka, K. (2000), "Creating and managing a high-performance knowledgesharing network. The Toyota case", Strategic Management Journal, Vol. 21, pp. 345-367.

Dyer, J.H. and Singh, H. (1998), “The relational view: Cooperative strategy and sources of interorganizational competitive advantage", Academy of Management Review, Vol. 23, No. 4, pp. 660-679.

Fischer, C. (1982), To dwell among friends, Chicago, University of Chicago Press.

Flynn, B.B. and Flynn, E.J. (2005), "Synergies between supply chain management and quality management emerging implications", International Journal of Production Research, Vol. 16, No. 15 , pp. $3421-3463$.

Fourth European Directive (2009):

http://europa.eu/legislation_summaries/internal_market/single_market_capital/126009_es.htm

Gabbay, S.M. and Leenders, R.T.A.J. (2001), "Social capital in organizations: From social structure to the management of corporate social capital", in S.M. Gabbay, R.T.A.J. Leenders (Ed.), Research in the sociology of organizations Oxford: JAI Press, Vol. 18, pp. 1-20.

García-Bernal, J., Gargalo-Castel, A., Pastor-Agustín, G. and Ramírez, M. (2004), “Total Quality Management in Firms. Evidence from Spain”, The Quality Management Journal, Vol. 11, No 3, pp. 20-34.

Geletkanycz, M.A. and Hambrick, D.C. (1997), “The external ties of top executives. Implications for strategic choice and performance", Administrative Science Quarterly, Vol. 42, No. 4, pp. 654-681.

Gilsing, V.A. and Duysters, G.M. (2008), "Understanding novelty creation in exploration networks. Structural and relational embeddedness jointly considered", Technovation, Vol. 28, pp. 693-708. 
Gómez-Gras, J.M. and Verdú, A.J. (2005), “TQM, Structural and Strategic Flexibility and Performance. An empirical research study", Total Quality Management, Vol. 16, No. 7, pp. 841-860.

Gotzamani, K.D. (2005), “The implications of the new ISO 9000.2000 standards for certified organizations", International Journal of Productivity and Performance Management, Vol. 54, No. 8, pp. 645-657.

Granovetter, M.S. (1973), "The strength of weak ties”, American Journal of Sociology, Vol. 78, pp. $1360-1380$.

Granovetter, M.S. (1982), "The strength of weak ties. A network theory revisited", in Marden, P. V. and Lin, N. (Ed.). Social structure and network analysis. Beverly Hills.

Granovetter, M. (2005), “The impact of social structure on economic outcomes”, Journal of Economic Perspectives, Vol. 19, No. 1, pp. 33-50.

Green, F. (2006), "Six Sigma and the revival of TQM", Total Quality Management \& Business Excellence, Vol. 17, No. 10, pp.1281-1286.

Gulati, R., Nohria, N. and Zaheer, A. (2000), "Strategic Networks", Strategic Management Journal, Vol. 21, pp. 203-215.

Gutiérrez-Gutiérrez, L.J., Tamayo-Torres, I. and Barrales-Molina, V. (2010), "Quality Management Initiatives in Europe: an Empirical Analysis according to Their Structural Elements", Total Quality Management \& Business Excellence. Vol. 21, No. 6.

Hackman, J.R. and Wageman, R. (1995), “Total Quality Management. Empirical, Conceptual, and Practical Issues", Administrative Science Quarterly, Vol. 40, No. 2, pp. 309-342.

Hallikas, J., Varis, J., Sissonen, H. and Virolainen, V. (2008), “The evolution of the networks in the ICT sector", International journal of production economics, Vol. 115, No. 2, pp. 296.

Hansen, E.L. (1995), “Entrepreneurial network and new organization growth", Entrepreneurship: Theory and Practice, Vol. 19, No. 4, pp. 7-19.

Hansen, M.T. (1999), "The search transfer problem: The role of weak ties in sharing knowledge across organization subunits", Administrative Science Quarterly, Vol. 44 No. 1, pp. 82-111.

Hofstede, G. (1980), "Motivation, leadership and organization: Do American theories apply abroad?", Organizational Dynamics, Vol. 9, pp. 42-63.

Howell, R.D. (1987), “Covariance Structure Modelling and Measurement Issues. A Note on 'Interrelations Among a Chanel Entity's Power Sources"', Journal of Marketing Research, Vol. 24, No. 2, pp. 119-126. 
Hulland, J. (1999), "Use of Partial Least Squares PLS in Strategic Management Research. A Review of Four Recent Studies”, Strategic Management Journal, Vol. 20, pp. 195-204.

Kang, E. (2008), "Director interlocks and spillover effects of reputational penalties from financial reporting fraud", Academy of Management Journal, Vol. 51, No 3, pp. 537-555.

Kaynak, H. (2003), "The relationship between total quality management practices and their effects on firm performance", Journal of Operations Management, Vol. 21, pp. 405-435.

Koste, L., Malhotra, M. and Shama, S. (2004), "Measuring dimensions of manufacturing flexibility", Journal of Operations Management, Vol. 22, pp. 171-196.

Krackhardt, D. (1992), "The strength of strong ties. The importance of philos in organizations", in Nohria N.and. Eccles, R.G (Ed.), Networks and Organizations, form and action, Cambridge, MA. Harvard Business School Press, pp. 216-239.

Kumar, M. and Antony, J. (2008), “Comparing the quality management practices in UK SMEs”, Industrial Management and Data Systems, Vol. 108, No. 9, pp. 1153.

Larson, A. (1992), "Network dyads in entrepreneurial settings. A study of governance of exchange relations", Administrative Science Quarterly, Vol. 37, No. 1, pp. 76-104.

Lee, C., Lee, K. and Pennings, J.M. (2001), "Internal capabilities, external networks, and performance: a study on technology-based ventures", Strategic Management Journal, Vol. 22, pp. 615-640.

Lessard, D.R. and Zaheer, S. (1996), "Breaking the silos: Distributed knowledge and strategic responses to volatile exchange rates", Strategic Management Journal, Vol. 17, pp. 513-533.

Liebeskind, J.P., Oliver, A.L., Zucker, L. and Brewer, M. (1996), "Social networks, learning, and flexibility. Sourcing scientific knowledge in new biotechnology firms", Organization Science, Vol. 7, No. 4, pp. 428-443.

Lin, C. and Chang, S. (2006), "Exploring TQM's impact on the causal linkage between manufacturing objective and organizational performance", Total Quality Management and Business Excellence, Vol. 17, No. 4, pp. 465-484.

Lin, C., Chow, W.S., Madu, C.N., Kuei, C. and Yu, P.P. (2005), “A structural equation model of supply chain quality management and organizational performance", International Journal of Production Economics, Vol. 96, pp. 355-365.

Lloréns-Montes, F.J., García-Morales, V.J. and Verdú-Jover, A.J. (2004), "Flexibility and quality management in manufacturing. An alternative approach", Production Planning and Control, Vol. 15, No. 5, pp. 525-533. 
Lloréns-Montes, F.J., Molina, L.M. and Verdú, A. (2005), "Flexibility of Manufacturing systems, strategic change and performance", International Journal of Production Economics, Vol. 98, pp. 273-289.

Lo, V.H.Y., Yeung, A.H.W. and Yeung, A.C.L. (2007), "How supply quality management improves on organization's quality performance: A study of Chinese manufacturing firms", International Journal of Production Research, Vol. 45, No. 15, pp. 2219-2243.

Lorenzoni, G.C. and Lipparini, A. (1999), "The leveraging of Inter-firm relationships as a distinctive organizational capability: A longitudinal study", Strategic Management Journal, Vol. 20, No. 4, pp. 317-338.

Lundmark, E. and Westelius, A. (2006), "Effects of Quality Management According to ISO 9000. A Swedish Study of the Transit to ISO 9000.2000", Total Quality Management and Business Excellence, Vol. 17, No. 8, pp. 1021-1042.

Macdonald, S. (1992), "Formal collaboration and informal information flow", International Journal of Technology Management, Vol. 7, No. 1-3, pp. 49-60.

Macdonald, S. (1995). "Learning to change. An information perspective on learning in the organization", Organization Science, Vol. 6, No. 5, pp. 557-568.Magd, H. and Curry, A. (2003), ISO 9000 and TQM: are they complementary or contradictory to each other?", The TQM Magazine, Vol.15, No. 4, pp. 244-256.

Manz, C. and Stewart, G. (1997), “Attaining Flexible Stability by Integrating Total Quality Management and Socio-technical Systems Theory", Organization Science, Vol. 8, No. 1, pp. 59.

Marsden, P.V. and Campbell, K. E. (1984), “Measuring tie strength”, Social Forces, Vol. 63, pp. $482-501$.

McAdam, R., Leonard, D., Henderson, J. and Hazlett, S. (2008), “A grounded theory research approach to building and testing TQM theory in operations management", Omega, Vol. 36, pp. 825-837.

McDonald, M.L. and Westphal, J.D. (2003), "Getting by with the advice of their friends: CEO's advice networks and firms' strategic responses to poor performance", Administrative Science Quarterly, Vol. 48, pp. 1-32.

McDonald, M.L., Khanna, P. and Westphal, J.D. (2008), "Getting them to think outside the circle. Corporate governance, CEOs' external advice networks, and firm performance", Academy of Management Journal, Vol.51, No. 3, pp. 453-475.

McEvily, B. and Marcus, A. (2005), "Embedded ties and the acquisition of competitive capabilities", Strategic Management Journal, Vol. 26, pp. 1033-1055. 
McEvily, B. and Zaheer, A. (1999), "Bridging ties: a source of firm heterogeneity in competitive capabilities”, Strategic Management Journal, Vol. 17, pp. 221-235.

Mellat-Parast, M. and Digman, L.A. (2007), “A framework for quality management practices in strategic alliances", Management Decision, Vol. 45, No. 4, pp. 802-818.

Mellat-Parast, M. and Digman, L.A. (2008), "Learning: The interface of quality management and strategic alliances", International Journal of Production Economics, Vol. 114, pp. 820829.

Merino-Díaz De Cerio, J. (2003), "Quality management practices and operational performance. Empirical evidence for Spanish industry", International Journal of Production Research, Vol. 41, No. 12, pp. 2763-2786.

Moran, P. (2005), "Structural vs. embeddedness. Social capital and managerial performance", Strategic Management Journal, Vol. 26, pp. 1129-1151.

Morrison, E.W. (2002), "Newcomers' relationships: the roles of social networks ties during socialization", Academy of Management Journal, Vol. 45, pp. 1149-1160.

Nadkarni, S. and Narayanan, V.K. (2007), "Strategic schemas, strategic flexibility, and firm performance. The moderating role of industry clockspeed", Strategic Management Journal, Vol. 28, pp. 243-270.

Nair, A. (2006), "Meta-analysis of the relationship between quality management practices and firm performance-implications for quality management theory development", Journal of Operations Management, Vol. 24, pp. 948-975.

Obstfeld, D. (2005), "Social networks, the tertius lungens orientation, and involvement in innovation", Administrative Science Quarterly, Vol. 50, pp. 100-130.

Park, S.H. and Lou, Y. (2001), "Guanxi and organizational dynamics. Organizational networking in Chinese firms", Strategic Management Journal, Vol. 22, No. 5, pp. 455-477.

Peng, M.W. and Lou, Y. (2000), "Managerial ties and firm performance in a transition economy. The nature of a micro-macro link", Academy or Management Journal, Vol. 43, No. 3, pp. 486-501.

Podsakoff, P.M. and Organ, D.W. (1986), "Self-reports in organizational research: Problems and prospects", Journal of Management, Vol. 12, pp. 531-544.

Powell, T.C. (1995), “Total Quality Management as Competitive Advantage: A review and empirical study”, Strategic Management Journal, Vol. 16, No. 1, pp. 15-37.

Powell, W. and Brantley, P. (1992), “Competitive cooperation in biotechnology. learning through networks?", in Nitin N.and Eccles R. (Ed.), Networks and organization, Boston, Harvard Business School Press, pp. 366-394. 
Prajogo, D.I. and Sohal, A.S. (2003), "The relationship between TQM practices, quality performance, and innovation performance. An empirical examination", International Journal of Quality and Reliability Management, Vol. 20, No. 8, pp. 901-918.

Prajogo, D.I. and Sohal, A.S. (2006), "The integration of TQM and technology/R\&D management in determining quality and innovation performance", Omega, Vol. 34, No. 3, pp. 296-312.

Rajagopal, S., Balan, S. and Scheuing, E. (1995), “Total quality management strategy. Quick fix or sound sense?", Total Quality Management, Vol. 6, No. 4, pp. 335-344.

Reagans, R. and McEvily, B. (2003), "Network structure and knowledge transfer. The effects of cohesion and range", Administrative Science Quarterly, Vol. 48, pp. 240-267.

Reagans, R. and Zuckerman, E. (2001), "Networks, diversity and performance: The social capital of RandD units”, Organization Science, Vol. 12, pp. 502-517.

Ruey-Kei, C. and Jason, C.H. (2005), “A generic service model for secure data interchange”, Industrial Management and Data Systems, Vol.105, No. 5/6, pp. 662.

Ryu, S. and Eyuboglu, N. (2007), "The environment and its impact on satisfaction with supplier performance: An investigation of the mediating effects of control mechanismsfrom the perspective of the manufacturer in the U.S.A.”. Industrial Marketing Management, Vol. 36, pp. 458-469.

Samuelsson, P. and Nilsson, L.E. (2002), "Self assessment practices in large organizations: Experiences from using the EFQM excellence model", The International Journal of Quality and Reliability Management, Vol.19, No. 1, pp.10-23.

Scott, J. (1991), Social network analysis, London, Sage.

Shimizu, K. and Hitt, M.A. (2004), "Strategic flexibility: Organizational preparedness to reverse ineffective strategic decisions", The Academy of Management Executive, Vol.18, No. 4, pp. 44.

Simon, H.A. (1959), "Theories of decision-making in economics and behavioural science", American Economic Review, Vol. 69, No. 3, pp. 253-283.

Sitkin, S.B., Sutcliffe, K.M. and Schroeder, R.G. (1994), "Distinguishing control from learning in Total Quality Management. a contingency perspective", Academy of Management Review, Vol. 19, No. 3, pp. 537-564.

Szulanski, G. (1996), "Exploring international stickiness. Impediments to the transfer of best practice within the firm", Strategic Management Journal, Vol. 17, pp. 27-43. 
Uzzi, B. (1996), "The resources and consequences of embeddedness for the economic performance of organizations. The network effect", American Sociological Review, Vol. 61, No. 4, pp. 674-698.

Van der Wiele, T., Van Iwaarden, J. and Williams, R. (2005), "Perceptions about the ISO 90002000 quality system standard revision and its value. The Dutch experience", International Journal of Quality and reliability Management, Vol. 22, No. 2, pp. 101-119.

Van Marrewijk, M., Wuisman, I., De Cleyn, W., Timmers, J., Panapanaan, V. and Linnaen, L. (2004), "A Phase-wise Development Approach to Business Excellence: Towards an Innovative, Stakeholder-oriented Assessment Tool for Organizational Excellence and CSR", Journal of Business Ethics, Vol.55, pp.83-98.

Verdú-Jover, A. J., Lloréns-Montes, F. J. \& García-Morales, V. J. (2004), “The concept of fit in services flexibility research: an empirical approach", International Journal of Service Industry Management, Vol. 15, No. 5, pp. 499-514. Volberda, H. W. (1996), "Toward the flexible form. How to remain vital in hypercompetitive environments", Organization Science, Vol. 7, No. 4, pp. 359-374.

Volberda, H.W. (1997), "Building flexible organizations for fast-moving markets", Long Range Planning, Vol. 30, No. 2, pp. 169-183.

Volberda, H.W. (1998), Building the flexible Firm. How to Remain Competitive. Oxford. Oxford University Press.

Von Hippel, E. (1988), The sources of innovation, New York, Oxford University Press.

Vouzas, F.K. and Gotzamani, K.D. (2005), "Best practices of selected Greek organizations on their road to business excellence. The contributions of the new ISO 9000.2000 series of standards", The TQM Magazine, Vol. 17, No. 3, pp. 259-266.

$\mathrm{Wu}$, L. (2006), "Resources, dynamic capabilities and performance in a dynamic environment. Perceptions in IT Taiwanese IT enterprises", Information and Management, Vol. 43, pp. 447-454.

Youssef, M.A., Boyd, J. and Williams, E. (1996), “The impact of total quality management on firm's responsiveness. An empirical analysis", Total Quality Management, Vol. 13, No. 6, pp. 813-825.

Zaccaro, S.J., Gilbert, J.A., Thor, K.K. and Mumford, M.D. (1991), "Leadership and social intelligence: linking social perspectiveness and behavioral flexibility to leader effectiveness", The Leadership Quarterly, Vol. 2, No. 4, pp. 317-342. 
Zaheer, A. and Bell, G.G. (2005), "Benefiting from network position. Firm capabilities, structural holes, and performance", Strategic Management Journal, Vol. 26, No. 9, pp. 809825.

Zaheer, A. and Zaheer, S. (1997), "Catching the wave. Alertness, responsiveness, and market influence in global electronic networks", Management science, Vol. 43, No. 11, pp. 14931509.

Zaheer, A., McEvily, B. and Perrone, V. (1998), "The strategic value of buyer-supplier relationships", International Journal of Purchasing and Materials Management, Vol. 34, No. 3, pp. 20-27.

Zairi, M. (2002), "Beyond TQM implementation. The new paradigm of TQM sustainability", Total Quality Management, Vol. 13, No. 8, pp. 1161-1172. 